\title{
Indicators of stable development of regional economy in conditions of post crisis period
}

\author{
Natalia Valerievna Gorshkova \\ Volgograd State University \\ Institute of Economics and Finances \\ Volgograd, Russia \\ GorshkovaNV@volsu.ru
}

\author{
Nikita Sergeevich Verkhovov \\ Saint-Petersburg Polytechnic University \\ after Peter the Great \\ Higher School of cyber-physical systems and management \\ Saint-Petersburg, Russia \\ nikita5555@bk.ru
}

\author{
Alyona Alexandrovna Polyanskaya \\ Volgograd State Technical University, \\ Faculty of Economics and Management \\ Volgograd, Russia \\ helenderbet@mail.ru
}

\begin{abstract}
The article is devoted to complex assessment of social \& economic development of - Volgograd region. A major task of regional authorities is preservation of real cash incomes of people and prevention of unemployment. The analysis of Volgograd region development indices has shown that the crisis period of 2008 had had a grave impact on economic stability of the region. The analysis of social $\&$ economic situation in the Volgograd region has shown that the region needs a special approach to maintain stable development, considering the structure of regional economy, efficiency of using resources, as well as social and ecological situation. The modern management system of regional development in Russia is not perfect and needs tools which can provide adequate assessment of regional social \& economic situation.
\end{abstract}

In the process of the scientific survey its authors reviewed alternative methods of assessing economic development of regions and used as a basic method for practical calculations the method of N.S. Davydova, which offers complex assessment of social, economic and ecological situation in a region.

The analysis of Volgograd region development indices (indicators) allowed us to rate the regional status as stable and come up with some practical measures aimed at stabilization of social \& economic situation.

Keywords - stable development, social \& economic situation, region, regional economy, growth indicators

\section{INTRODUCTION}

Problems, hindering stable regional development in the Russian Federation, can be grouped along the following lines:
- missing conceptual approach to spatial development of the country, identifying main priorities, relating to particular regions;

- limited set of tools to control regional development;

- lack of common typology of regions, designed to differentiate for each type of territory available indices and parameters of the current policy.

Summarizing methodological approaches, used in the Russian and world practice to formation of index system of social \& economic regional development, we can highlight the following principal characteristics of indices:

- Necessity in using only quantitative parameters;

- Possibility to reflect social \& economic and ecological situation of a system under review;

- Using data only from official sources;

- Easy data collection;

- Tracing the dynamics of system transformation in time;

- Unambiguous interpretation of results;

- Possibility of comparative analysis regarding other objects;

- Possibility to take management decisions based on analysis results. 
Achieving stable development - is a major vital problem, facing Russian regions and the country as a whole and its solution can help smooth regional differences. Transition to stable development will trigger economic growth, preserving resources for generations to come [1]. Regional development is a functional mode of regional system, aimed at positive dynamics regarding the level and quality of life. Stable regional development is achieved by balanced and multi-factor dynamics of social \& economic situation in a region, its resource and ecological potential [2].

The purpose of this paper is to provide a comprehensive analysis of indices (indicators) of Volgograd region development as information basis for planning, forecasting and taking management decisions at the regional level.

\section{MATERIALS AND MethodS (MODEL)}

The social \& economic policy supporting stable development of regions in the Russian Federation is affected by a number of internal and external factors. First of all, all regions have different economic potential and competitive advantages, capable of adaptation according to new economic conditions. Secondly, the scope of state investments in regional development is insufficient. Economic specialization of regions, formed in the Soviet period, insufficiently stimulates private investment, development and implementation of new technologies. Thirdly, important role in economic relations is played by actual inequality of different Russian Federation subjects. Regions differ by rates of privatization or agricultural reform, development of market infrastructure and entrepreneur activity, by degree of participation in foreign economic activity and in solving general state economic problems, like, problems of pumping up the budget; regions also differ by scope of attracted foreign investments. All these factors determine the unique nature of Russian regional situation and a result, impossibility to use positive foreign experience in assessing stable development.

Management of regional development can be performed by means of a wide scope of concrete actions, using which the local administration stimulates development of regional economy, creates new jobs, increases the taxation basis, expands opportunities for new economic activities, popular with the local community.

Stability of regional development can be assessed by many indices. Used as a basis of calculation was the assessment system of regional stability development, proposed by N.S. Davydova. We highlighted eleven indices, being fairly important for assessment of stable development. All indices are split by subsystems: economic, social and ecological.

The degree of regional development stability can be high, medium, low. Threshold values are established for each index to assess its impact on stability of regional development as follows. Each stability status is described by the system of indices, having certain limit points - system transition by this index from one status to another. Stability degree:

$$
\begin{aligned}
& \text { - High }->1 \\
& \text { - Medium }-0,75<x i * y<1
\end{aligned}
$$

\section{- Low $-<0,75$}

Each index is rated by importance; weight factor of all indices in each subsystem does not exceed 1.

\section{RESULTS AND DISCUSSION}

So, we shall analyze only internal regional indices of stable regional development. Chosen for this analysis was a Russian Federation subject - Volgograd region. Sources of information are official data of the Federal Statistical Service for the period 2005-2015.

In accordance with chosen indices of stable regional development and their threshold values, we will calculate each index as per weight factors in the period 2005-2015 for the Volgograd region. As shown in Table 2, we can speak about high stability of the Volgograd region since 2013; this period can be rated as peak in economic development of the Volgograd region and in the Russian economy as a whole. During 2005-2015 we observe stable investments in fixed assets, affecting ROI of sales. Growth index of consumer prices and services went up as compared to the previous year. Higher index of consumer prices reflects the fact that the standard basket of goods and services became more expensive in comparison with the previous year; average annual growth of consumer price index was $10-12 \%$. The number of loss making businesses increased and so did the unemployment level in the region.

The social subsystem also enjoys positive dynamics. We see modest growth of average monthly wages, $5-10 \%$ a year. The share of population with incomes below subsistence level goes down.

However, in the ecological subsystem we observe instability, on one hand less pollution of the atmosphere in $\%$ to previous year, on the other hand less investment in fixed assets, spent on protection of environment and rational use of natural resources.

In 2014 the world was confronted with financial \& economic crisis, resulting in plummeting of key economic indices in most regions of the country, affecting dramatically their stability. As you see in Table 2, we observe after 2014 less stable development of the Volgograd region.

Most difficult was the period of 2009-2010, when stability indices dropped to minimum. Unemployment level in 20092010 was $8,0 \%$. In conditions of the crisis, the state presence in the investment market went up, increasing slightly the share of budget funding.

Stabilty of the Volgograd region development started to intensively improve. In 2015, despite new problems in the 
Russian economy, index of stable development in the Volgograd region continued to go up.

The degree of Volgograd region stable development started to intensively improve in 2015 despite new problems in the Russian economy.

Table 1 - System of indices to assess stability of regional development
This is illustrated by the summary graph, showing the level of stable development in the Volgograd region, incorporating indices and threshold value (Fig. 1).

\begin{tabular}{|c|c|c|c|c|}
\hline \multirow[t]{2}{*}{ Stability indices, $\mathrm{x}_{\mathrm{i}}$} & \multicolumn{3}{|c|}{ Degree of stability } & \multirow[t]{2}{*}{ weight, $\mathrm{y}$} \\
\hline & low & medium & high & \\
\hline \multicolumn{5}{|l|}{ Economic subsystem } \\
\hline Physical volume index Gross Region. Product, in \% to prev. year & Below 100 & From 100 to 110 & Above 110 & 0,2 \\
\hline Investment in fixed assets, in \% to prev. year & Below 100 & From 100 to 110 & Above 110 & 0,2 \\
\hline Percentage of loss making businesses, $\%$ & Higher 50 & From 10 to 50 & Below 10 & 0,15 \\
\hline Rate of return on sales, $\%$ & Below 9 & From 9 to 13 & Above 13 & 0,15 \\
\hline Unemployment level, \% & Higher 8 & From 4 to 8 & Below 4 & 0,2 \\
\hline Index of consumer prices, $\%$ & Higher 110 & From 105 to 110 & Below 105 & 0,1 \\
\hline \multicolumn{5}{|l|}{ Social subsystem } \\
\hline Average monthly salary, $\%$ to prev. year & Below 100 & From 100 to 110 & Above 110 & 0,3 \\
\hline Share of population with incomes below subsistence level & Higher 30 & From 10 to 30 & Below 10 & 0,3 \\
\hline Real cash earnings (to previous period), $\%$ & Below 100 & From 100 to 110 & Above 110 & 0,4 \\
\hline \multicolumn{5}{|l|}{ Ecological subsystem } \\
\hline Emission of pollutants to atmosphere, in $\%$ to prev. year & Higher 100 & From 100 to 90 & Below 90 & 0,6 \\
\hline $\begin{array}{l}\text { Investment in fixed assets, spent on environmental protection and } \\
\text { rational use of natural resources, in } \% \text { to prev. year }\end{array}$ & Below 100 & From 100 to 110 & Above 110 & 0,4 \\
\hline Stability factor & 0,75 & $0,75<x<1$ & 1 & \\
\hline
\end{tabular}

Table 2 - Calculation of development stability in Volgograd region [3]

\begin{tabular}{|c|c|c|c|c|c|c|c|c|c|c|c|}
\hline \multirow[t]{2}{*}{ Stability indices } & \multicolumn{11}{|c|}{ Degree of stability, $x_{i} * y$} \\
\hline & 2005 & 2006 & 2007 & 2008 & 2009 & 2010 & 2011 & 2012 & 2013 & 2014 & 2015 \\
\hline \multicolumn{12}{|l|}{ Economic subsystem } \\
\hline $\begin{array}{l}\text { Physical volume index Gross } \\
\text { Region. Product, in \% to } \\
\text { prev. year }\end{array}$ & 21,04 & 20,34 & 21,4 & 21,14 & 17,4 & 20,74 & 20,66 & 20,56 & 20,28 & 20,94 & 18,76 \\
\hline $\begin{array}{l}\text { Investment in fixed assets, in } \\
\% \text { to prev. year }\end{array}$ & 19,88 & 19,88 & 19,88 & 19,88 & 19,88 & 19,88 & 19,82 & 19,92 & 19,82 & 19,88 & 19,82 \\
\hline $\begin{array}{l}\text { Percentage of loss making } \\
\text { businesses, \% }\end{array}$ & - & - & - & - & - & - & - & - & 4,239 & 5,0625 & 5,2125 \\
\hline Rate of return on sales, $\%$ & - & - & - & - & - & - & 1,32 & 1,32 & 1,2 & 1,305 & 1,47 \\
\hline Unemployment level, \% & - & - & - & - & 1,6 & 1,6 & 1,38 & 1,2 & 1,32 & 1,32 & 1,44 \\
\hline Index of consumer prices, $\%$ & - & - & 11,17 & 11,31 & 10,88 & 10,95 & 10,53 & 10,66 & 10,54 & 11,2 & 11,32 \\
\hline \multicolumn{12}{|l|}{ Social subsystem } \\
\hline $\begin{array}{l}\text { Average monthly salary, \% } \\
\text { to prev. year }\end{array}$ & - & - & - & - & - & - & - & 28,59 & 32,7 & 31,71 & 33,115 \\
\hline $\begin{array}{l}\text { Share of population with } \\
\text { incomes below subsistence } \\
\text { level }\end{array}$ & - & - & - & - & - & - & 4,53 & 4,08 & 4,08 & 4,2 & 4,35 \\
\hline $\begin{array}{lll}\text { Real cash earnings } & \text { (to } \\
\text { previous period), } \% & \\
\end{array}$ & - & - & - & - & - & - & - & 41,64 & 40,8 & 40,04 & 39,96 \\
\hline \multicolumn{12}{|l|}{ Ecological subsystem } \\
\hline $\begin{array}{l}\text { Emission of pollutants to } \\
\text { atmosphere, in \% to prev. } \\
\text { year }\end{array}$ & - & - & 136,14 & 132,84 & 116,94 & 120,66 & 106,92 & 102,54 & 103,68 & 92,1 & 96 \\
\hline $\begin{array}{l}\text { Investment in fixed assets, } \\
\text { spent on environmental } \\
\text { protection and rational use of } \\
\text { natural resources, in } \% \text { to } \\
\text { prev. year }\end{array}$ & - & - & 31,84 & 31,48 & 24,84 & 24,12 & 10,28 & 5,4 & 9,6 & 0,88 & 19,52 \\
\hline Stability factor & 0,4 & 0,4 & 2,2 & 2,16 & 1,9 & 1,98 & 1,75 & 2,36 & 2,48 & 2,29 & 2,5 \\
\hline
\end{tabular}


As is shown by the graph, the economic situation in Russia and in the world affects differently the social \& economic situation in different regions of the country, interfering with stable regional development.

\section{CONCLUSION}

Analysis of the Volgograd region shows that despite similarity by territorial location to other regions of the Russian Federation, spheres of economic activity, as well as development level of the social sphere, there is a big gap by development stability between regions as separate systems.

This problem is typical for all subjects of the Russian Federation. To a large extent, the stable development of a particular region depends upon the level of self-sustenance, self-financing, self-sufficiency and economic independence. The problem of assessing stable development is vital, especially in the period when we overcome the consequences of global economic crisis. We should review in detail the problems of regional stable development in Russia, as well as assess efficiency of existing methods on evaluating stable development of Russian Federation subjects. Thus, application of methodological approaches to comprehensive assessment of indicators of stable regional development is of vital importance, especially when overcoming the consequences of the world economic crisis.

\section{References}

1. Factors of sustainable development of Russian regions: monograph / V. V. Sinitsyna, Gayfutdinova O. S., etc. / ed. S. Chernov. - Book 6. - Novosibirsk: CRS, 2009. - $326 \mathrm{p}$.

2. Our common future / / / report of the world Commission on environment and development (WCED). - Moscow: Progress, 1989.

3. Official site of Federal state statistics service http://www.gks.ru/

4. Alternative sources of business development: Mezzanine financing.P. and again.A. Angina, E. A. Makarova, N. In. Gorshkova, K. D. Ban / / proceedings of Pardubice University, Series D: faculty of Economics and management. - 2016. - Thom. 23 g. № 37 (2/2016). - P. $143-155$.

5. Competitive advantages of the University of regional support and its role in the strategy of regional development.P. Son, E. E. Harlow, N. In. Gorshkova, E. A. I / Nauka I obschestvo (a / a). - 2016. - No. 3 (v1). S. $180-189$.

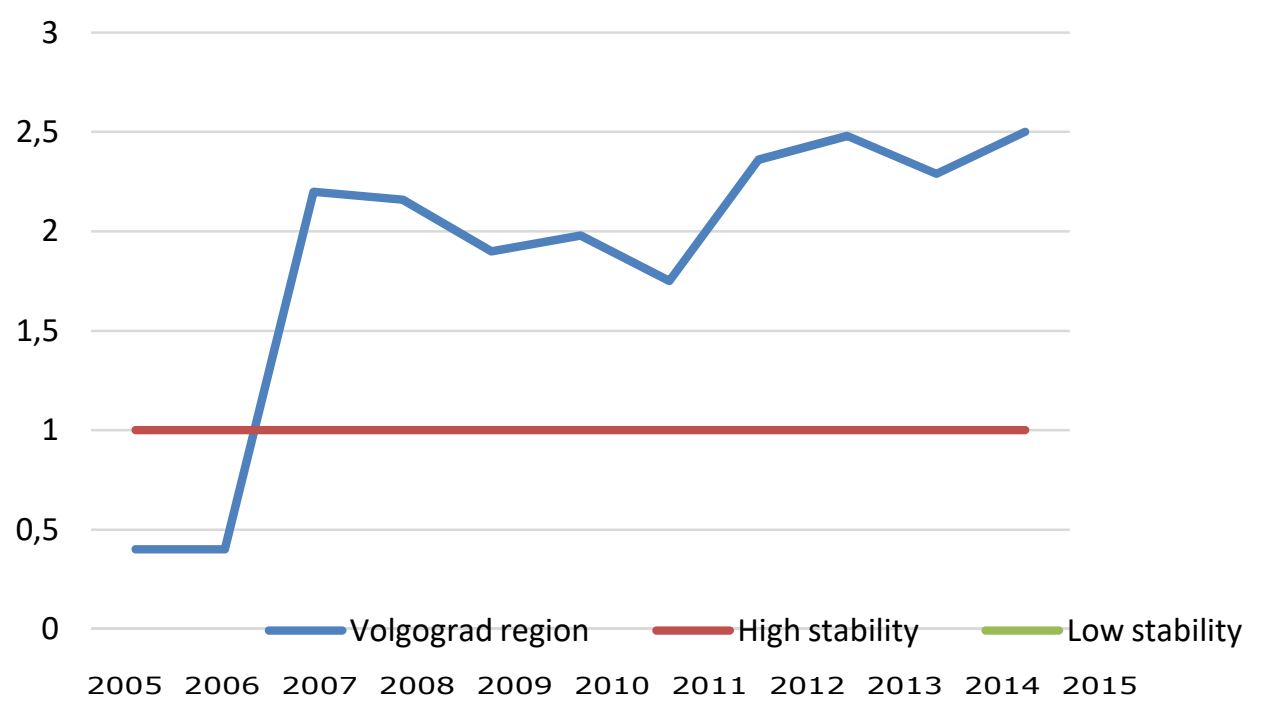

Figure 1-Sustainable development Factors of the Volgograd region for the period 2005-2015 